\title{
The Profession of Teacher in Digital World
}

\author{
Elena G. Tareva* (a), Boris V. Tarev (b) \\ (a) Moscow City University, 129226, Moscow (Russia), 4-1, $2^{\text {nd }}$ Selskokhoziastvenny Proezd, \\ (b) National Research University Higher School of Economics, 101000, Moscow (Russia), 20 \\ Myasnitskaya street, $\underline{\text { boristarev@mail.ru }}$
}

\begin{abstract}
Mankind has faced new challenges related to the development of the Internet era, and the formation of a digital society, digital (global) consciousness, a new axiosphere associated with the development of all forms of digitalization and networking. Due to the expansion of the information space to a state of unlimited, weak or impossible assessment of its reliability, there are risks of manipulating consciousness through the "soft power" of politics, art, and education. Such risks can be mitigated by education, which, during the period of widespread digitalization, must find answers to new challenges related to the education of a person in a network society. The article deals with the preparation of a new generation of teachers with new "digital" abilities, ready to overcome the challenges of our time. The empirical study addresses the issue of the range of digital teacher professions needed for life and work in the emerging Industry 4.0. The authors formulate the conditions under which the teacher's readiness to implement digital technologies in educational practice can be achieved.
\end{abstract}

Keywords: family Digital society; digital professions; pedagogical activity.

\section{(C) 2020 Elena G. Tareva, Boris V. Tarev}

This is an open access article distributed under the terms of the Creative Commons Attribution License (CC BY 4.0), which permits unrestricted use, distribution, and reproduction in any medium, provided the original author and source are credited.

Published by Kazan federal university and peer-reviewed under responsibility of IFTE-2020 (VI International Forum on Teacher Education)

\footnotetext{
* Corresponding author. E-mail: TarevaEG@mgpu.ru
} 


\section{Introduction}

Network society is a space in which people coexist in different ways using digital technologies (Redshaw, 2019). Some, being born in this society, perceive it as something natural and unique (Laidlaw, O’Mara \& So Har Wong, 2019). Others entered this world without conflict during the period of growing up and mastering new knowledge. Some others have become active users of the Internet environment and web opportunities due to production/professional need. The fourth remain aloof from technological innovations, being cautiously involved in the "digital world" because of vital necessities. A new wave in the development of mankind, connected with the precepts of the post-industrial and postinformation society, left no one behind, implementing digital economy, creating open administrative environments through digital technologies, introducing digital technologies into creative performances, determining the digital path for the development of education. Network relations, network activity (for example, gaming), network training are of interest for everyone - both participants and non-participants; the latter often usually act as critics.

Digital opportunities have expanded the living space of a person. Such an expansion, first of all, deals with complication of human capabilities: memory restructuring (due to its interfacing with an external information storage), perceptual abilities (connecting new perception channels), mental activity with the aim of modeling and designing ways to achieve goals and objectives, expanding communication skills through collaborative interaction with people from all over the world. Models and methods of interactionism and communicative processes have changed significantly (Housley \& Smith, 2014; Reyna, Hanham \& Meier, P., 2018). It proves the importance of digital media principles to develop effective communication in the digital space. Students now require knowledge of these principles, in conjunction with conceptual and functional skills, for effective communication in the digital space. This is one of the conditions for the development of a collective (global) mind, combining the creative abilities, skills, experience of many people in their focus on solving the urgent problem that has arisen.

Because of the changed world, a period has come when the ideology of stability, stability, and equilibrium has acquired a limited scale (Poulos, 2002). A person should be ready for irrational decisions, unexpected actions, changes in the usual way of life, and changes in professional orientation. He should have a tolerance for uncertainty, a willingness to live in a "strange" world, when change is the natural norm of life. The subject of social systems should be ready for the transition from the SPOD world (S - steady; P predictable; O - ordinary; D - definite) to the VUCA world (V - volatility; U - uncertainty; C complexity; A - ambiguity). 
The focus on the development of an individual who is ready and capable of living in a digital space with competencies necessary for Industry 4.0, involves a change in the understanding of the world, people's thinking, their behavior and ways of interaction. An individual of the era of digital economy should be ready for constant development of his potential, for changes in professional specialization, for cardinal changes in its environment. According to E. Toffler, with the transition to digital economy, changes are taking place not only in the field of computerization (which was characteristic of the industrial era), but also in the post-industrial relation of a person to work, nation, leisure, authority, etc. (Toffler, 1980). There is a need to review various types of relationships: human attitude to nature, relations between social groups, relations between people, relation to the past, present, future.

\section{Purpose and objectives of the study}

The purpose of the study is to reveal the features of the modern portrait of a teacher from the point of view of his readiness to carry out professional activities in the conditions of Industry 4.0. We want to show the variability of the teaching profession, its openness to innovations, to prove its ability to change depending on external factors and circumstances. The ultimate goal of the study is to represent digital pedagogical professions - new forms and types of activities of a future teacher with the competence to use IT technologies in the educational process.

\section{Literature review}

With the development of a network society, new "digital" professions arise, the old "analog" ones disappear (Kirschner \& Stoyanov, 2020). These trends are characteristic for the era of information society which is called postmodernism (Bokova \& Malakhova, 2019). Digital technologies in combination with big data and predictive analytics are having a significant impact upon social, professional practices at different levels (individual, organisational, national, international). The interplay of code, algorithms and big data are significantly dominant in the management, leadership and practices of different professional groups ( Švarc, 2015).

In the contemporary and future world, people will be required to work longer. At the same time, their employment will become more and more insecure due to technological advances and obsolescence of acquired knowledge and skills. New professional staff with special abilities is needed. This means that something must happen in the education and training of younger generations.

New abilities have been studied and classified more than once (see, for example, Fenwick \& Edwards (2015); Skills for a digital world (2016). According to Fenwick and Edwards (2015), using a group concept 
mapping procedure, experts in different fields (educators, educational researchers, human resource professionals, etc.) generated 239 ideas with regard to the trigger statement: "One specific way to prepare youth to make effective and efficient use of information skills to optimally function in tomorrow's labour market is..." Here are the basic 15 thematic clusters: Critical Thinking, Skills Transfer, High-Level Thinking, Competences, Metacognition and Reflection, Efficacy [Self-Image] Building, Learn in Authentic Situations, Integrate School and Profession, Collaboration, Teacher Professionalization, Information Literacy, Redesign the School, Literacy, and Numeracy, Information Skills, and Learn for the Future. The research specifies the ways of adaption education to prepare youth for shortly nonexistent/not yet existing professions (Fenwick \& Edwards, 2015).

For their implementation, it is necessary to pose and solve issues related to the reformatting of the educational environment, with its orientation towards the inclusion in its traditional format of everything that could prepare the younger generation for life in a network society, for activities in situations of uncertainty, unforeseenness, and decision making in a variety of options.

In modern conditions, the educational system should acquire the following features necessary for an innovative economy and post-industrial society:

- basic training will be combined with the variability of opportunities for advanced training and retraining;

- the social characteristics of various educational routes that actually provide academic mobility of students will come closer / intersect;

- ample opportunities for project work will ensure students' adaptability to new social / professional environment with its changing characteristics and rapidly changing requirements;

- there will be an integration of education and production in order to ensure joint work at the forefront of modern science;

- the proportion of students' independent work, the degree of their involvement in real research projects will be significantly increased;

- the system of educational counseling and support for continuing education will be widely developed;

- the competitiveness of Russian education, ready to generate innovations, will be increased (Tareva, 2015).

The achievement of these indicators of the educational system is possible only if a teacher has a new style of thinking and activities related to network technologies that ensure the optimization of the educational process and the formation of a person of the future. 


\section{Methodology}

In the educational context, network (digital) technologies have been studied for decades. A very impressive bulk of knowledge has been accumulated about educational environments, electronic educational resources, educational platforms, computer educational products. At the same time, the strategy of accumulating knowledge in this area developed along an extensive path: the number of computer tools applicable in education grew, they "joined" to a particular pedagogical problem, fixing the entire researcher's attention on the digitalization of the learning environment, and not on the problem of its exposure on a human. As a result, a huge bank of computer training resources was formed, the array of which was not subjected to proper classification, expert assessment and analysis.

The consideration of digital educational practices has long been removed from the profession and the activities of the teacher. Initially, it was assumed that he a priori should have the ability to develop an electronic educational product, fill it with content, and create a technology for its application. A paradox has formed: on the one hand, there is a totality of educational digital resources, on the other hand, teachers who are poorly oriented in this array, do not possess or have poor ability to select a product, check its quality, and include it in educational reality.

Being based on the research (Esteve-Mon, Cela-Ranilla \& Gisbert-Cervera, 2016), empirical diagnostic methods (surveys, questionnaires, interviews) revealed the leading trends in this area within the period of years 2017-2019. As a result of a survey of teachers $(\mathrm{N}=657)$ of higher education, three categories of specialists were identified in terms of their level of application of online educational resources (see Table 1):

Table 1. Categories of teachers (IT experience)

\begin{tabular}{|c|c|c|c|c|}
\hline Year & Total N of participants & IT Designers & IT Users & IT Non-Users \\
\hline $\mathbf{2 0 1 7}$ & 218 & 12 & 100 & 106 \\
\hline $\mathbf{2 0 1 8}$ & 234 & 20 & 116 & 98 \\
\hline $\mathbf{2 0 1 9}$ & 205 & 27 & 133 & 45 \\
\hline
\end{tabular}

The data obtained indicate that the growth of the number of those teachers who successfully use electronic resources to achieve educational goals is obvious. This indicates their digital competence. In direct proportion, the number of those teachers who do not have experience with electronic services is reduced. 
The results show that a virtual environment should function smoothly and have simple interfaces, realistic scenes, and interactive activities.

The conclusions made are confirmed by the data obtained in the course of a number of diagnostic studies. For instance, the study (Maderick et al., 2015) verifies the fact that teachers themselves in the process of self-assessment confirm the growth of their digital competence. Another research (David, Bruce \& Chiu, 2015 ) proves the ability of teachers to design a digital video content that leads to the increase in quality of English language education.

It can be concluded that the dissemination of leading trends aimed at optimizing the educational environment through the use of digital technologies runs into the teacher's inability to use these technologies. As a result, traditional models of training and education are still used, which not always work effectively for students - representatives of the digital society.

\section{Results}

In connection with the current situation, there is a need to review and diversify the orientation of the pedagogical profession, to change the vector of its movement towards the development of new digital practices. The needs of today affect the classic look of the teacher, make him change, adapting to the new requirements of the digital model of social development.

Changes due to time require a need in digital pedagogical professions, which, in particular, is stated in the Atlas of new professions (http://atlas100.ru/). The functional of the teaching profession, while maintaining the classic set of professional competencies, should be replenished with the following possible options:

- designer and / or curator of specialized educational online platforms and educational games, having pedagogical experience, ${ }^{\circ}$ understanding the content of the student's activities, knowing how to model the educational trajectory of the student on the created platform;

- responsible for the "gameplay" of educational platforms and applications: an analyst evaluating the usefulness of new services and technologies;

- editor of online training lessons, whose job responsibilities include watching educational videos and displaying thematic tags;

- game engineer - a scriptwriter for educational games, adapting the curriculum to the game, turning it into a story with interesting tasks and goals for students - gamers; 
- coach for blended learning, which does not transmit knowledge, but controls the student's independent work using Internet resources;

- an instructor in Internet surfing, which helps to separate the important from the unimportant in the abundance of multicode information, to identify the true and false (similar to fact checking), matching and different in the cultural facts extracted from the Internet;

- an interdisciplinary tutor supervising the student's personal trajectory in his development in contact with other teachers;

- developer of educational trajectories - a specialist who creates educational routes for students, taking into account their inclinations, personality orientation and needs;

- project specialist helping students create projects.

The development of these specialized areas of training for higher education teachers will allow changing the educational space and creating conditions for preparation of new generation specialists who are ready to solve the problems posed by the world of digital technologies.

\section{Discussions}

The specific features of the competences of an agent in Industry 4.0 lies in the fact that their components (knowledge, skills, personal traits) are characterized by the dynamics of the life cycle, they must be flexible, capable of adapting to new conditions and development. This is such a person that the education system should prepare, and the speed of introducing the ideology of the digital economy depends on the success of this educational system. Education today faces new challenges that must be addressed as soon as possible. Teacher training requires updating, taking into account the needs of the educational priorities of the digital economy (STEM education; STEM = science, technology, engineering, mathematics - a term commonly used in determining educational methodology and design of the curriculum in schools in order to increase competitiveness in the field of science development and technology). The future belongs to technology, and the future of technology belongs to teachers of a new format who are free from prejudice, reject a formal approach and can prepare with their knowledge agents of Industry 4.0 and expand the horizons of students.

\section{Conclusion}

New time dictates new demands in the field of reformatting the Russian educational system. Such reformatting is associated with the dissemination and adoption of a "digital education" aimed at training 
personnel who are in demand of the priorities of a network society. The task of the teacher training system is to take into account new directions in the development of society and the state, priorities that are associated with the introduction of breakthrough ideas, and on this basis to build new educational paths that require not only a change in the content component, but also the training of fundamentally new teaching staff that can easily adapt to requirements of the digital world. Our argument is that new digital technologies are reconfiguring professional practice and responsibility, but that the education of professionals has yet to adequately reflect these changes.

\section{Acknowledgements}

Our thanks to Vladimir Potanin's Charity Fund for supporting the study.

\section{References}

Bokova, T. N., \& Malakhova, V. G. (2019). Postmodernism as the dominant of education development in the information society. The European Proceedings of Social \& Behavioural Sciences EpSBS, 173-180.

David, L., Bruce, D. L., \& Chiu, M. M. (2015). Composing with new technology: Teacher reflections on learning digital video. Journal of Teacher Education, 66(3), 272-287.

Esteve-Mon, F. M., Cela-Ranilla, J. M., \& Gisbert-Cervera, M. (2016). ETeach3D: Designing a 3D virtual environment for evaluating the digital competence of preservice teachers. Journal of Educational Computing Research, 54(6), 816-839.

Fenwick, T., \& Edwards, R. (2015). Exploring the impact of digital technologies on professional responsibilities and education. European Educational Research Journal, 15(1), 117-131.

Housley, W., \& Smith, R. J. (2017). Interactionism and digital society. Qualitative Research, 17(2), 187-201.

Kirschner, P. A., \& Stoyanov, S. (2020). Educating youth for nonexistent/not yet existing professions. Educational Policy, 34(3), 477-517.

Laidlaw, L., O’Mara, J., \& So Har Wong, S. (2019). 'This is your brain on devices': Media accounts of young children's use of digital technologies and implications for parents and teachers. Contemporary Issues in Early Childhood. 
Maderick, J. A., Zhang, S., Hartley, K., \& Marchand, G. (2015). Preservice teachers and self-assessing digital competence. Journal of Educational Computing Research, 54(3), 326-351.

Poulos, C. N. (2002). The death of ordinariness: Living, learning, and relating in the age of anxiety. Qualitative Inquiry, 8(3), 288-301.

Redshaw, T. (2019). What is digital society? Reflections on the aims and purpose of digital sociology. Sociology, 1-7.

Reyna, J., Hanham, J., \& Meier, P. (2018). The Internet explosion, digital media principles and implications to communicate effectively in the digital space. E-Learning and Digital Media, 15(1), $36-52$.

Organisation for Economic Co-operation and Development. (2016). Skills for a digital world: 2016 Ministerial Meeting on the Digital Economy. Background Report. OECD Digital Economy Papers, No. 250, OECD Publishing, Paris, https://doi.org/10.1787/5jlwz83z3wnw-en.

Švarc, J. (2015). The knowledge worker is dead: What about professions? Current Sociology, 64(3), 392-410.

Tareva, E. G. (2015). Evolution of Foreign Language Teaching Practices: Optimistic Projection. Bulletin of the Moscow City Pedagogical University. Series: Philology. Language theory. Language education, 2(18), 75-85.

Toffler, A. (1980). The third wave. William Morrow and Co., Inc. New York. 